ELORE (ISSN 1456-3010), vol. 20 - 1/2013.

Julkaisija: Suomen Kansantietouden Tutkijain Seura ry.

[http://www.elore.fi/arkisto/1_13/pk_stranden-backa_lukin.pdf]

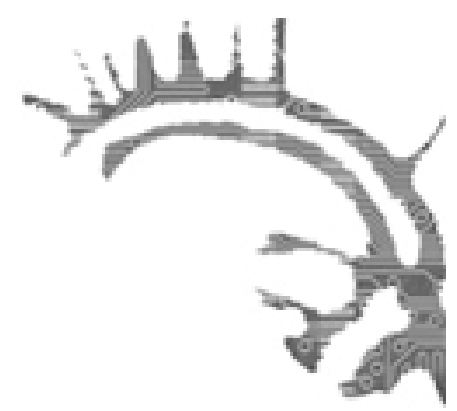

\title{
LEDAREN
}

\section{OBEROENDE FORSKNING OCH VETENSKAP MED EFTERTANKE}

\section{$\underline{\text { Sofie Strandén-Backa och Karina Lukin }}$}

I slutet av rapporten "Sininen kirja" ("Den blå boken") som skrevs som en del av statsrådets framtidsforskningsprojekt befinner vi oss vid dödsbädden och frågar den döende hur livet har varit. Med hjälp av denna metafor försöker rapportens skribent filosofen Pekka Himanen åskådliggöra att individens liv och i förlängningen också samhällets verksamhet borde ha som grund en strävan efter ett värdigt liv. Den nu i stort sett bortglömda rapporten lyfts fram i en artikel utgiven av Long Play (Silfverberg \& Vehkoo 2013). Long Play är en publikationskanal som flaggar för så kallad långsam journalistik, och detta var deras andra singel, deras andra publikation.

Long Play ger ut djuplodande och genomtänkta artiklar - en helt annan typ av journalistik än den som gör nätnyheter som är lagom långa för datorns bildskärm. Artiklarna marknadsförs med ord som kvalitet och oberoende, värden, som också hyllas och försvaras i den akademiska världen.

Den omfattande reform som den nuvarande regeringen har förberett för statens forskningsinstitut och forskningsfinansieringen har däremot väckt farhågor om en snöpt forskning, sjunkande kvalitet och om att den oberoende forskningen hotas eller går om intet. På universiteten oroar man sig för en fördunkling av relationen mellan forskning och politik - i praktiken för att forskningsresultaten inte ska vara oberoende. Den oberoende forskningens metoder föds emellertid ur vetenskaplig debatt, som har sin grund i ifrågasättande, öppen diskussion samt bildningsideal.

Artikeln i Long Play lyfte fram ett problem som har kallats för konsultdemokrati (Kuusela \& Ylönen 2013). Detta innebär att regeringen använder rapporter gjorda av 
privatföretag som stöd och underlag för sina beslut. Utgångspunkterna, materialet, metoderna och slutresultaten är inte alls alltid öppna - inte heller oberoende. I rapporterna har politik maskerats som vetenskap. Många befarar att den reform av forskningsinstituten som regeringen skisserat ska göra forskningsinstituten till ett slags programmerbara maskiner som ger beslutsfattarna den "kunskap" den vill ha. På dödsbädden, om man följer Himanens resonemang, skulle oberoendet, den öppna diskussionen, sanningssträvan och bildningsidealet finnas. God forskning eller, som Long Play visar, god journalistik får trots allt ändå ofta synlighet, eftersom den går på djupet, diskuterar öppet och oberoende av förhandsantaganden. En utmaning ligger dock i att få redan existerande god forskning att nå såväl beslutsfattare som allmänhet. Som alltid vill Elore vara med i denna typ av vetenskaplig debatt.

I det här numret av Elore lyfter vi fram ett forskningsområde som börjat debatteras ivrigt, ett forskningsområde som lockar allt fler: humanistisk djurforskning. Numret med djur som tema har två gästande artikelredaktörer: Taija Kaarlenkaski och Sari UngLanki. Nora Schuurman har ombetts skriva kolumnen till detta nummer. Artiklarna kretsar kring djur och människor, och relationen dem emellan ur många synvinklar, och vi kan här erbjuda sex artiklar och två översikter på temaområdet. I Kaarlenkaskis och Ung-Lankis introduktionstext finns en översikt av forskningsfältet, och för en snabb inblick i artikelinnehållet hänvisar vi till abstracten som finns på finska, svenska och engelska. Förutom de gästande artikelredaktörerna har Tuija Hovi, Elina Hytönen-Ng, Karina Lukin och Sofie Strandén-Backa arbetat med artiklarna, och Tintti Klapuri med översikterna.

Utöver artiklarna i temanumret finns det också som vanligt mycket aktuellt vetenskapligt att läsa i Elore. I det förra numret (2/2012) skrev Sven-Erik Klinkmann en artikel som skärskådade sociologen Riie Heikkiläs doktorsavhandling om stereotyper om det finlandssvenska. I föreliggande nummer finns ett genmäle av Heikkilä och hennes handledare professor Keijo Rahkonen. Klinkmann har getts möjlighet att bemöta deras genmäle, och hans svarsinlägg finns att läsa i det här numret.

Flera rapporter om olika vetenskapliga aktualiteter finns också samlade i detta nummer. Här publiceras även fyra lectio praecursoria: Kari Huuskonens "Vaietut historiat ja perinteet" ("Tystade historier och traditioner"), Niina Hämäläinens "Kalevalan moderni ilme" ("Moderna uttryck av Kalevala"), Taija Kaarlenkaskis "Ystävä ja tuotantoväline. Lehmä suomalaisten kirjoitetuissa kertomuksissa" ("Vän och produktionsredskap. Kon i finska skrivna berättelser"), samt Mikael Sarlins "Om mörker, maskuliniteter, humor och lek inom black metal". Arbetet med aktualitetstexterna har i detta nummer gjorts av Tiina Seppä, Johanna Björkholm, Tuomas Hovi, Kirsi-Maria Hytönen, Antti Lindfors och Kaisa Nissi. Något som vi särskilt vill lyfta fram bland aktualiteterna är att professor Pekka Hakamies fyllde 60 år i april, och firades med ett seminarium och en festskrift. Antti Lindfors har skrivit en rapport från festligheterna i Åbo. Elore ställer sig som en i raden av de många gratulanterna. Våra hjärtligaste gratulationer på bemärkelsedagen, Pekka!

Efter aktualiteterna finns som tidigare en hel drös med recensioner av böcker som hänför sig till Elores intresseområden. Karina Lukin, Heidi Haapoja och Ulla Savolainen har arbetat med dessa. Vi tackar också Andreas Backa för hjälpen med svensk kor- 
rekturläsning. Översättningsarbetet har gjorts av Tuija Hovi, Karina Lukin och Sofie Strandén-Backa. Vi vill också här tacka alla de många anonyma refereegranskare som har sett till att hålla kvaliteten hög på de publicerade artiklarna.

Det här numret har kommit till genom nära samarbete mellan hela tre chefsredaktörer: Elina Hytönen-Ng, Karina Lukin och Sofie Strandén-Backa. Elina blev mammaledig i slutskedet av arbetet med numret, och Karina ställde sig till förfogande som vikarie för henne. Grattis Elina till babyn! Nu önskar vi alla goda lässtunder med Elore 1/2013.

\section{KÄLLOR}

HIMANEN, PEKKA 2012: Sininen kirja. Suomen kestävän kasvun malli. Luonnos kansalliseksi tulevaisuushankkeeksi. Valtioneuvosto [online] <http://valtioneuvosto. fi/tiedostot/julkinen/pdf/2012/sininen-kirja/fi.pdf> [28.3.2013.]

KUUSELA, HANNA \& YLÖNEN, MATTI 2013: Konsulttidemokratia. Miten valtiosta tehdä̈̈n tyhmä ja tehoton. Helsinki: Gaudeamus.

SILFVERBERG, ANU \& VEHKOO, JOHANNA 2013: Himasen etiikka - Long Play 2. 